\title{
CORRIGENDUM
}

\section{The history of the International Journal of Technology Assessment in Health Care}

Egon Jonsson

University of Alberta and University of Calgary and Institute of Health Economics

\section{Stanley J. Reiser}

The George Washington University

doi:10.1017/S0266462309090357, published by Cambridge University Press, 9 July 2009

Table 2. Country Representation on the Editorial Board of the International Journal of Technology Assessment in Health Care as of 2009
Argentina
Australia
Austria
Belgium
Canada
China
Finland
France
Germany
Israel
Italy
Japan
Mexico
The Netherlands
New Zealand
Norway
Scotland
Singapore
Spain
Sweden
United Kingdom
United States
Vietnam
WHO

Due to an oversight, Israel was omitted from the Table 2 on page 15 of the article titled "The history of the International Journal of Technology Assessment in Health Care" by Egon Jonsson and Stanley J. Reiser (1) in International Journal of Technology Assessment in Health Care, Volume 25 Supplement 1 ("History of HTA"). We regret the omission. The corrected table appears below.

\section{REFERENCE}

1. Jonsson E, Reiser SJ. The history of the International Journal of Technology Assessment in Health Care. Int J Technol Assess Health Care. 2009;25:Supplement 1:11-18. 